\title{
Pengaruh Konsentrasi Giberelin (Ga3) Dan Lama Perendaman Dalam Meningatkan PerkecambahanBenih Padi (Oryza sativa L.) Varietas Ciherang (Kadaluarsa)
}

\author{
Azhar Mubarok¹, Jenal Mutakin² Dan Resti Fajarfika² \\ Prodi Agroteknologi, Fakultas Pertanian, Univesitas Garut \\ Jalan Raya Samarang Nomor 52.A, Garut. \\ e-mail : azharmubarok9@gmail.com
}

\begin{abstract}
Abstrak
Penelitian ini dilaksanakan untuk mengetahui pengaruh kombinasi konsentrasi $\mathrm{GA}_{3}$ dan lamanya perendaman dalam meningkatkan perkecambahan benih padi (Oryza Sativa L.) varietas Ciherang kadaluarsa dengan metode pengujian viabilitas dan vigor. Percobaan dilaksanakan pada bulan Agustus sampai September 2019 di Laboratoriumterpadu Fakultas Pertanian Universitas Garut Kecamatan Tarogong Kabupaten Garut,Metode yang digunakan adalah eksperimental dengan menggunakan Rancangan AcakLengkap (RAL) pola faktorial 5 x 3 dengan 3 ulangan. Faktor pertama adalah konsentrasi $\mathrm{GA}_{3}(\mathrm{G})$, terdiri dari kontrol positif $\left(\mathrm{g}_{0}\right)$, kontrol negatif $\left(\mathrm{g}_{1}\right)$, konsentrasi GA $38 \mathrm{ppm}\left(\mathrm{g}_{2}\right)$, konsentrasi $\mathrm{GA}_{3} 16 \mathrm{ppm}\left(\mathrm{g}_{3}\right)$, konsentrasi $\mathrm{GA}_{3} 24 \mathrm{ppm}\left(\mathrm{g}_{4}\right)$. Faktor kedua adalah lamanya perendaman $(\mathrm{P}), 12 \mathrm{jam}\left(\mathrm{p}_{1}\right), 24$ jam $\left(\mathrm{p}_{2}\right), 36$ jam $\left(\mathrm{p}_{3}\right)$. Parameteryang diamati adalah kadar air, kecepatan tumbuh, indeks vigor, daya berkecambah, potensi tumbuh maksimum, panjang kecambah dan berat kering kecambah normal. Hasil penelitian menunjukan interaksi antara konsentrasi $\mathrm{GA}_{3}$ dan lamanya perendaman terhadap kecepatan tumbuh pada uji viabilitas dan tidak terjadi interaksi terhadap kecepatan tumbuh uji vigor, indeks vigor, daya berkecambah, potensi tumbuhmaksimum, panjang kecambah dan berat kering kecambah normal pada uji viabilitas dan vigor.
\end{abstract}

Kata kunci: Ciherang, Giberelin, Perendaman, Viabilitas, Vigor.

\section{Abstract}

This study was conducted to determine the effect of a combination of $G A_{3}$ concentrationand duration of immersion in increasing the germination of rice seeds (Oryza Sativa L.) of expired Ciherang varieties by the viability and vigor testing methods. The experiment was conducted in August to September 2019 in the integrated Laboratory of the Faculty of Agriculture, University of Garut, District of Tarogong, Garut Regency. The method used was experimental using a completely randomized design (RAL) of 5 x 3 factorial patterns with 3 replications. The first factor is the concentrationof $G A_{3}(G)$, consisting of positive 
control $\left(g_{0}\right)$, negative control $\left(g_{1}\right)$, concentration of GA3 8 ppm $\left(g_{2}\right)$, concentration of $\mathrm{GA}_{3}$ $16 \mathrm{ppm}\left(\mathrm{g}_{3}\right)$, concentration of $\mathrm{GA}_{3} 24 \mathrm{ppm}\left(\mathrm{g}_{4}\right)$.The second factor is the duration of immersion $(P), 12$ hours $\left(p_{1}\right), 24$ hours $\left(p_{2}\right), 36$ hours $\left(p_{3}\right)$. The parameters observed were water content, growth speed, vigor index, germination capacity, maximum growth potential, germination length and normal germination dry weight. The results showed an interaction between $G_{3}$ concentrationand duration of immersion on the growth speed in the viability test and no interaction occurred on the growth speed of the vigor test, vigor index, germination, maximum growth potential, germination length and normal germination dry weight in the viability and vigor test.

Keywords: Ciherang, Gibberellins, Soaking, Viabilityy, Vigor.

\section{Pendahuluan}

Padi (Oryza sativa L.) merupakan tanaman pangan yang banyak dibudidayakan di Indonesia karena sebagai makanan pokok dan lebih dari 95\% penduduk Indonesia mengonsumsi beras sebagai sumber karbohidrat. Rata-rata konsumsi beras di Indonesiapada tahun 2017 mencapai $81.611 \mathrm{~kg}$ kapita/tahun (Pusat Data dan Informasi Pertanian,2018). Nilai gizi yang terkandung dalam 100 gr beras giling adalah Energi 366 kalori, Protein 7,6 gr, Lemak 1 gr, Karbohidrat 78,9 gr, serat 0,4 gr, Kalsium 59 mg, Pospor 258 mg, Besi 0,8 mg, dan Vitamin B1 0,26 mg (Dapartemen kesehatan RI, 1995).

Produksi padi di Indonesia pada tahun 2014 sebanyak 70.846/ton, tahun 2015 meningkat menjadi 75.398/ton, tahun 2016 sebanyak 79.365/ton dan tahun 2017sebanyak 81.149/ton (Pusat Data dan Informasi Pertanian, 2018). Persentase rata-rata kenaikan produksi padi meningkat setiap tahunnya. karena itu, harus ada upaya untukmenjaga produksi padi di Indonesia agar terus meningkat dengan memperhatikan beberapa faktor yang dapat mempengaruhi produksi yaitu ketersedian benih yang bermutu, kondisi lingkungan yang sesuai untuk pertumbuhan padi, teknik budidaya dan organisme pengganggu tanaman (Nugrohotomo dan Syukur, 2009).

Ketersediaan benih yang bermutu sangat diperlukan agar produksi beras berkualitas baik, salah satu varietas yang sudah dibudidayakan adalah Ciherang yang memiliki kelebihan diantaranya rata-rata hasil produksi mencapai 7,2 ton/ha danrasanya pulen (Balai Besar Penelitian Tanaman Padi, 2009).

Zat pengatur tumbuh merupakan senyawa organik yang dapat merangsang maupun menghambat pertumbuhan, serta dapat mempengaruhi pola pertumbuhan tanaman (Wattimena, 2000). Salah satunya adalah giberelin (Asam giberelat) yang banyak dijual dipasaran adalah $\mathrm{GA}_{3}$. Menurut Hopkin (1995), giberelin sangat berperan dalam pembelahan sel, pematahan dormansi, pertumbuhan, perpanjangan tunas dan mobilisasi endosperm selama perkecambahan. meskipun tumbuhan dapat menghasilkan $\mathrm{GA}_{3}$ namun belum mencukupi untuk merangsang perkecambahan terutama untuk biji yang keras (Asra dan 
Ubaidilah, 2012).

Lama perendaman bertujuan untuk memberi kesempatan biji dapat menyerap air sehingga dapat merangsang benih untuk berkecambah, waktu yang berbeda selama perendaman dimaksudkan untuk mengetahui waktu yang paling sesuai dalam pematahan dormansi sehingga mampu melunakkan dan membuka pori-pori kulit benih yang keras (Nurshanti, 2013). Informasi tentang benih padi varietas Ciherang yang sudah kadaluarsa diberi perlakuan $\mathrm{GA}_{3}$ belum banyak diteliti. karena itu, perlu adanya penelitian terkait hal tersebut.

\section{Metodologi}

Penelitian dilaksanakan di Laboratorium terpadu Fakultas Pertanian Universitas Garut Kabupaten Garut pada bulan Agustus sampai September 2019. Bahan yang digunakan yaitu benih padi varietas Ciherang tanggal kadaluarsa sampai 10 Juli 2019 (melewati masa kadaluarsa 43 hari), benih padi varietas Ciherang tanggal kadaluarsa sampai 7 November 2019 (belum melewati masa kadaluarsa), kertas buram, air hangat, 1 butir $\mathrm{GA}_{3} 20 \%$, akuades, alkohol 70\%, karet gelang, kardus dan plastik. Alat yang digunakan yaitu germinator, oven, gelas ukur, keranjang, labu ukur, mistar, erlenmayer, autoclave, timbangan analitik, timbangan digital, pipet, sprayer, pinset, alat tulis, jam, kertas label dan kamera.

Penelitian ini menggunakan Rancanangan Acak Lengkap (RAL) dengan pola faktorial dengan 2 faktor dengan 3 kali ulangan. konsentrasi $\mathrm{GA}_{3}(\mathrm{~g})$ terdiri dari 5 tarafyaitu : $\mathrm{g}_{0}=$ kontrol positif (benih padi varietas Ciherang belum melewati masakadaluarsa), $\mathrm{g}_{1}=$ kontrol negatif (benih padi varietas Ciherang kadaluarsa), $\mathrm{g}_{2}=8 \mathrm{ppm}, \mathrm{g}_{3}=16 \mathrm{ppm}$ dan $\mathrm{g}_{4}=24 \mathrm{ppm}$. Lama prendaman $(p)$ terdiri dari 3 taraf yaitu : $p_{1}=12$ jam, $p_{2}=24$ jam dan $p_{3}=36$ jam. Jika terdapat pengaruh nyata pada perlakuan yang diuji maka dilakukan uji lanjutan dengan menggunakan uji Jarak Berganda Duncan (Duncan Multiple Range Test) pada taraf 5\% (Gomez dan Gomez, 2010).

Benih padi yang belum kadaluarsa diberi perlakuan lama perendaman saja sedangkan benih padi yang sudah kadaluarsa direndam dengan $\mathrm{GA}_{3}$ dan diuji viabilitas dengan menggunakan media kertas buram digulung dilapisi plastik dan diletakan pada nampan dengan dibantu menggunakan alat germinator. untuk uji vigor menggunakan kardus diisi dengan menggunakan pasir sebagai media tanam. Parameter pengamatan terdiri dari :

\section{Kadar Air Benih (\%)}

Mengukur kadar air benih dengan cara mengambil sampel benih sebanyak $100 \mathrm{gr}$ kemudian masukan ke dalam alat tecalor diulang sampai 3 kali.

\section{Kecepatan tumbuh (Kct) hasil (etmal\%)}

Pengamatan dilakukan dengan mengamati benih yang dapat tumbuh normal setiap 
pagi hari selama 7 HST (Tefa, 2017) dengan menggunakan rumus sebagai berikut :

$$
\text { Kct } \%=\left(\% \frac{K N}{\text { etmal }}\right)={ }_{\Sigma^{t n}} \frac{N}{{ }^{t o}}
$$

Keterangan :

$\begin{array}{ll}\text { Kct } & : \text { Kecepatan tumbuh } \\ \text { Kn } & : \text { Kecambah normal } \\ 1 \text { etmal } & : 1 \text { hari pengamatan } \\ \text { tn } & : \text { Hari Pengamatan ke }-7 \\ \mathrm{~N} & : \text { Kecmbah normal pada setiap harinya } \\ \mathrm{T} & : \text { waktu pengamatan ke i }\end{array}$

\section{Indeks Vigor (IV) hasil (\%)}

Pengamatan dilakukan dengan mengamati benih yang dapat tumbuh secara normalpada perhitungan pertama (first count) yaitu pada hari ke 5 HST (International Seed Testing Association, 2010) dengan menggunakan rumus sebagai berikut :

$$
I V(\%)=\frac{\sum \text { kecambah normal pengamatan pertama }}{\sum \text { Beni } h \text { yang ditanam }} \times 100 \%
$$

\section{Daya berkecambah (DB) hasil (\%)}

Daya berkecambah diamati dengan cara menghitung kecambah yang normal padadengan hitungan pertama pada hari ke 5 HST dan hitungan ke 2 pada hari ke 7 HST (Tefa, 2017) dengan menggunakan rumus sebagai berikut :

$$
D B(\%)=\frac{\sum K N 1+\sum K N 11}{\sum \text { Benih yang ditanam }} \times 100 \%
$$

Keterangan:

$\mathrm{KN} \quad=$ kecambah Normal

$\sum K N \mathrm{I}=$ Pengamatan pertama 5 HST

$\sum K N$ II $=$ Pengamatan kedua 7 HST

\section{Potensi Tumbuh Maksimum (PTM) hasil (\%)}

Potensi tumbuh maksimum diamati dengan cara menghitung semua kecambah yang dapat tumbuh normal maupun abnormal pada pengamatan hari ke 7 HST (Tefa, 2017) dengan menggunakan rumus sebagai berikut : 


$$
\operatorname{PTM}(\%)=\frac{\sum \text { Benih yang tumbuh }}{\sum \text { Benih yang ditanam }} \times 100 \%
$$

\section{Panjang Per Kecambah (cm)}

Mengukur panjang kecambah pada hari ke 7 dengan cara mengukur kecambah normal dengan menggunakan mistar, dengan cara mengukur bagian ujung akar sampai tajuk kecambah normal.

\section{Berat Kering Kecambah Normal (mg)}

Berat kering kecambah normal merupakan uji viabilitas potensial yang menggambarkan banyaknya cadangan makanan yang tersedia sehingga mampu tumbuh dengan baik. untuk melakukan uji BKKN dengan mengambil semua kecambahnormal pada hari pengamatan ke 7 dengan cara dikeringkan dengan menggunakan ovendengan suhu $60^{\circ} \mathrm{C}$ selama 72 jam, kecambah yang sudah melewati tahap ovenkemudian didinginkan terlebih dahulu sebelum ditimbang. Rumus yang digunakan untuk menghitung BKKN dengan cara berat kering dibagi kecambah yang dioven (International Seed Testing Association, 2010).

\section{Hasil dan Pembahasan}

\section{Kadar Air Benih (\%)}

Hasil pengujian benih dengan menggunakan alat tecalor menunjukkan bahwa kadar air benih padi varietas Ciherang kadaluarsa dan yang belum melewati masa kadaluarsa mengalami penurunan kadar air seperti yang ditunjukkan Tabel 1.

Tabel 1. Kadar air benih padi varietas Ciherang (\%)

\begin{tabular}{lcc}
\hline & $\begin{array}{c}\text { Varietas Ciherang } \\
\text { Kadaluarsa }\end{array}$ & $\begin{array}{c}\text { Varietas Ciherang Tidak } \\
\text { Kadaluarsa }\end{array}$ \\
\hline Keterangan Label & 12 & 12,9 \\
Hasl Pengujian & 11,5 & 12 \\
\hline
\end{tabular}

Tabel 1 menunjukkan bahwa kadar air benih padi varietas Ciherang mengalami penurunan sebesar $0.5-0.9 \%$, hal tersebut diduga pada saat penyimpanan mempengaruhi tingkat kadar air benih yang dapat mempengaruhi kondisi benih tersebut selama disimpan. seperti tempat penyimpanan benih terkena sinar matahari langsung sehingga suhu dan kelembabannya tidak terjaga dan menyebabkan terjadinyaperubahan kadar air benih.

Ance dan Kartasapoetra (1992) menyatakan bahwa kandungan air yang terdapat di dalam benih memegang peranan yang sangat penting untuk menjaga kualitas benih pada saat penyimpanan sehingga kemampuan benih untuk tumbuh setelah lamanya penyimpanan bisa terjaga semaksimal mungkin dan tidak mengalami penurunan cepat.Kadar air terendah pada 
saat penyimpanan untuk benih Inbrida adalah $11 \%$ sedangkankadar air tertinggi adalah $13 \%$ (Direktorat Perbenihan, 2009).

\section{Kecepatan Tumbuh Uji Viabilitas}

Hasil analisis menunjukkan bahwa terjadi interaksi antara konsentasi $\mathrm{GA}_{3}$ dan lama perendaman dalam meningkatkan kecepatan tumbuh benih padi varietas Ciherangkadaluarsa pada Uji Viabilitas seperti yang ditunjukkan Tabel 2.

Tabel 2. Interaksi kombinasi konsentasi $\mathrm{GA}_{3}$ dan lama perendaman (\%)

\begin{tabular}{cccc}
\hline \multirow{2}{*}{ Konsentrasi GA 3} & \multicolumn{3}{c}{ Perlakuan } \\
\cline { 2 - 4 } & $12 \mathrm{jam}\left(\mathrm{p}_{1}\right)$ & $24 \mathrm{jam}\left(\mathrm{p}_{2}\right)$ & $36 \mathrm{jam}\left(\mathrm{p}_{3}\right)$ \\
\cline { 2 - 4 } & $18.4 \mathrm{~d}$ & $18.95 \mathrm{c}$ & $20.38 \mathrm{~d}$ \\
Kontrol positif $\left(\mathrm{g}_{0}\right)$ & $\mathrm{A}$ & $\mathrm{AB}$ & $\mathrm{B}$ \\
& $10.87 \mathrm{a}$ & $12.81 \mathrm{~b}$ & $12.88 \mathrm{a}$ \\
Kontrol negatif $\left(\mathrm{g}_{1}\right)$ & $\mathrm{A}$ & $\mathrm{B}$ & $\mathrm{B}$ \\
& $12.69 \mathrm{~b}$ & $14.86 \mathrm{~b}$ & $14.68 \mathrm{~b}$ \\
$\mathrm{GA}_{3} 8 \mathrm{ppm}\left(\mathrm{g}_{2}\right)$ & $\mathrm{A}$ & $\mathrm{B}$ & $\mathrm{B}$ \\
& $14.73 \mathrm{c}$ & $12.88 \mathrm{a}$ & $14.46 \mathrm{c}$ \\
$\mathrm{GA}_{3} 16 \mathrm{ppm}\left(\mathrm{g}_{3}\right)$ & $\mathrm{B}$ & $\mathrm{A}$ & $\mathrm{C}$ \\
& $13.1 \mathrm{~b}$ & $15.35 \mathrm{~b}$ & $17.05 \mathrm{c}$ \\
$\mathrm{GA}_{3} 24 \mathrm{ppm}\left(\mathrm{g}_{4}\right)$ & $\mathrm{A}$ & $\mathrm{B}$ & $\mathrm{B}$ \\
& & & \multicolumn{3}{c}{ Laman } & \\
\hline
\end{tabular}

Keterangan: Angka rata-rata yang diikuti huruf yang sama pada arah vertikal dan Horizontal, tidak berbeda nyata berdasarkan Uji Jarak Berganda Duncanpada taraf nyata $5 \%$. kontrol positif $\left(\mathrm{g}_{0}\right)=$ Benih padi Ciherang belum melewati masa kadaluarsa dan kontrol negatif $\left(\mathrm{g}_{1}\right)=$ Benih padi Ciherangkadaluarsa .

Tabel 2 menunjukkan bahwa Pengaruh perlakuan kombinasi GA 324 ppm dengan perendaman selama 36 jam terhadap benih padi varietas Ciherang kadaluarsa belum mampu mengimbangi kecepatan tumbuh benih padi varietas Ciherang yang belum melewati masa kadaluarsa $\left(g_{0}\right)$ yang hanya diberi perlakuan perendaman saja selama 36 jam. Wahyuni (2011) menyatakan bahwa aplikasi $\mathrm{GA}_{3} 10$ ppm selama 24 jam mampu meningkatkan kecepatan tumbuh $2.1-4.3 \%$ pada benih hibrida mutu awal sedang.

Giberelin berperan penting dalam pematahan dormansi dan merangsang benih untuk berkecambah lebih cepat, tingginya konsentrasi dan lamanya waktu perendaman dapat menyebabkan penyerapan air untuk pengaktifan enzim yang berguna untuk proses perombakan cadangan makanan serta mempercepat aktivitas pembelahan dan pembesaran sel untuk mempercepat pertumbuhan benih (Vici dkk., 2017). Pengaruh giberelin terhadap biji dapat mendorong dalam pemanjangan sel sehingga radikula dapat menembus endosperm yang membatasi pertumbuhan biji (Salisbury dkk., 1995).

\section{Kecepatan Tumbuh Uji Vigor}

Hasil analisis menunjukkan tidak terjadi interaksi antara konsentrasi GA 3 dan lama 
perendaman namun terjadi pengaruh secara mandiri perlakuan konsentrasi $\mathrm{GA}_{3}$ dan lamanya perendaman dalam meningkatkan kecepatan tumbuh (Kct) benih padi varietas Ciherang kadaluarsa seperti yang ditunjukkan Tabel 3 .

Tabel 3 menunjukkan bahwa pengaruh mandiri pemberian konsentrasi $\mathrm{GA}_{3} 24$ ppm pada benih padi varietas Ciherang kadaluarsa mampu meningkatkan kecepatan tumbuh sampai $7.12 \%$ dibandingkan dengan benih padi varietas Ciherang kadaluarsa $\left(\mathrm{g}_{1}\right)$ yang hanya diberi perlakuan perendaman saja dengan hasil $4.19 \%$.

Tabel 3. Kecepatan tumbuh Uji Vigor (\%)

\begin{tabular}{lll}
\hline & Perlakuan & Kct $(\%)$ \\
\hline & Kontrol positif $\left(\mathrm{g}_{0}\right)$ & $8.52 \mathrm{c}$ \\
Konsentrasi $\mathrm{GA}_{3}$ & Kontrol negatif $\left(\mathrm{g}_{1}\right)$ & $4.19 \mathrm{a}$ \\
& $\mathrm{GA}_{3} 8 \mathrm{ppm}\left(\mathrm{g}_{2}\right)$ & $6.33 \mathrm{~b}$ \\
& $\mathrm{GA}_{3} 16 \mathrm{ppm}\left(\mathrm{g}_{3}\right)$ & $6.88 \mathrm{bc}$ \\
Lama Perendaman & $\mathrm{GA}_{3} 24 \mathrm{ppm}\left(\mathrm{g}_{4}\right)$ & $7.12 \mathrm{bc}$ \\
& 12 jam $\left(\mathrm{p}_{1}\right)$ & 5.5 \\
& 24 jam $\left(\mathrm{p}_{2}\right)$ & $6.72 \mathrm{ab}$ \\
& 36 jam $\left(\mathrm{p}_{3}\right)$ & $7,59 \mathrm{~b}$ \\
\hline
\end{tabular}

Keterangan: Angka rata-rata yang diikuti huruf yang sama pada arah vertikal, tidak berbeda nyata berdasarkan Uji Jarak berganda Duncan pada taraf nyata 5\%. kontrol positif $\left(\mathrm{g}_{0}\right)=$ Benih padi Ciherang belum melewati masa kadaluarsa dan kontrol negatif $\left(\mathrm{g}_{1}\right)=$ Benih padi Ciherang kadaluarsa.

Menurut Sutopo (2002), fase awal benih membutuhkan air untuk memulai berkecambah, karena benih akan memulai proses imbibisi yang mengakibatkan kulit benih melunak sehingga terjadi hidrasi protoplasma yang mengaktifkan enzim-enzim untuk proses benih berkecambah. Proses perombakan cadangan makanan mengahasilkan energi yang diikuti pembentukan senyawa protein untuk pembentukan sel baru yang diikuti proses diferensiasi sel-sel sehingga terbentuk plumula dan radikula (Supardy dkk., 2016).

\section{Indeks Vigor Uji Viablitas dan Uji Vigor}

Hasil analisis menunjukkan tidak terjadi interaksi antara konsentrasi GA 3 dan lama perendaman namun terjadi pengaruh secara mandiri perlakuan pemberian konsentrasi $\mathrm{GA}_{3}$ dan lama perendaman terhadap indeks vigor (IV) benih padi varietas Ciherang pada Uji Viabilitas dan Vigor seperti yang ditunjukkan Tabel 4.

Tabel 4 menunjukkan bahwa pengaruh mandiri konsentrasi $\mathrm{GA}_{3}$ terhadap indeks vigor benih padi varietas Ciherang kadaluarsa pada uji viabilitas dan vigor. Pemberiankonsentrasi $\mathrm{GA}_{3} 8 \mathrm{ppm}$ pada uji viabilitas memberikan hasil tertinggi sebesar $81.22 \%$ dibandingkan dengan benih padi varietas Ciherang tanpa perlakuan pemberian $\mathrm{GA}_{3}\left(\mathrm{~g}_{1}\right)$ dengan hasil mencapai $66.66 \%$ dan perendaman selama 36 jam mampu meningkatkan indeks vigor benih padi varietas Ciherang sebesar $84.86 \%$ dibandingkandengan perendaman selama 12 jam dengan hasil mencapai $74.46 \%$. 
Tabel 4. Indeks Vigor pada Uji Viabilitas dan Uji Vigor (\%)

\begin{tabular}{llcc}
\hline & Perlakuan & Uji Viabilitas & Uji Vigor \\
\hline & & IV $(\%)$ & IV $(\%)$ \\
\hline \multirow{4}{*}{ Kontrol positif $\left(\mathrm{g}_{0}\right)$} & $92.88 \mathrm{c}$ & $51.11 \mathrm{c}$ \\
& Kontrol negatif $\left(\mathrm{g}_{1}\right)$ & $66.66 \mathrm{a}$ & $4.88 \mathrm{a}$ \\
& $\mathrm{GA}_{3} 8 \mathrm{ppm}\left(\mathrm{g}_{2}\right)$ & $81.22 \mathrm{~b}$ & $26.33 \mathrm{~b}$ \\
& $\mathrm{GA}_{3} 16 \mathrm{ppm}\left(\mathrm{g}_{3}\right)$ & $79.11 \mathrm{~b}$ & $36.33 \mathrm{bc}$ \\
& $\mathrm{GA}_{3} 24 \mathrm{ppm}\left(\mathrm{g}_{4}\right)$ & $80 \mathrm{~b}$ & $41.77 \mathrm{bc}$ \\
\hline Lama Perendaman & 12 jam $\left(\mathrm{p}_{1}\right)$ & $74.46 \mathrm{a}$ & $26.06 \mathrm{a}$ \\
& 24 jam $\left(\mathrm{p}_{2}\right)$ & $80.6 \mathrm{~b}$ & $32.37 \mathrm{a}$ \\
& 36 jam $\left(\mathrm{p}_{3}\right)$ & $84.86 \mathrm{c}$ & $38.21 \mathrm{a}$ \\
\hline
\end{tabular}

Keterangan: Angka rata-rata yang diikuti huruf yang sama pada arah vertikal, tidak berbeda nyata berdasarkan Uji Jarak berganda Duncan pada taraf nyata 5\%. kontrol positif $\left(\mathrm{g}_{0}\right)=$ Benih padi Ciherang belum melewati masa kadaluarsa dan kontrol negatif $\left(\mathrm{g}_{1}\right)=$ Benih padi Ciherang kadaluarsa.

Pengaruh konsentrasi $\mathrm{GA}_{3} 24 \mathrm{ppm}$ mampu meningkatkan indeks vigor benih Ciherang kadaluarsa sampai $41.77 \%$ dibandingkan dengan benih padi varietas Ciherang kadaluarsa ( $\left.g_{1}\right)$ tanpa perlakuan hanya bisa mencapai $4.88 \%$, pemberian $\mathrm{GA}_{3}$ hampir mengimbangi indeks vigor benih padi varietas Ciherang belum melewati masakadaluarsa $\left(\mathrm{g}_{0}\right)$ pada uji vigor namun pada uji viabilitas pengaruh mandiri $\mathrm{GA}_{3}$ tidak mampu mengimbangi indeks vigor benih padi varietas Ciherang belum melewati masakadaluarsa $\left(\mathrm{g}_{0}\right)$, dikarenakan benih yang sudah kadaluarsa sudah mengalami penurunanpada saat lamanya penyimpanan dan juga faktor yang dapat mempengaruhi indeks vigor menurun bisa disebabkan oleh benih terjangkit penyakit saat penyimpanan di gudang maupun pada saat penangkaran di lapangan sehingga benih terbawa penyakit kemungkinan besar menyebar pada saat penyimpanan.

\section{Daya Berkecambah Uji Viabilitas dan Uji Vigor}

Hasil analisis menunjukkan tidak terjadi interaksi antara konsentrasi $\mathrm{GA}_{3}$ dan lama perendaman namun terjadi pengaruh secara mandiri konsentrasi $\mathrm{GA}_{3}$ dan lama perendaman pada daya berkecambah (DB) benih padi varietas Ciherang kadaluarsa pada Uji Viabilitas dan Vigor seperti yang ditunjukkan Tabel 5.

Tabel 5. menunjukkan bahwa pengaruh mandiri konsentrasi $\mathrm{GA}_{3}$ terhadap daya berkecambah benih padi varietas Ciherang kadaluarsa pada uji viabilitas terdapat perlakuan tertinggi yaitu pemberian konsentrasi $\mathrm{GA}_{3} 8 \mathrm{ppm}$ memberikan hasil daya berkecambah mencapai $80.05 \%$ dibandingkan dengan benih padi kadaluarsa tanpa menggunakan $\mathrm{GA}_{3}\left(\mathrm{~g}_{1}\right)$ mencapai $70.72 \%$. Lama perendaman 36 jam merupakan perlakuan terbaik meningkatkan daya berkecambah benih padi varietas Ciherangsampai 83.72\%.

Perlakuan konsentrasi $\mathrm{GA}_{3} 8$ ppm mampu mengembalikan daya berkecambah benih padi varietas Ciherang kadaluarsa sehingga memenuhi standar yang ditentukan yaitu daya berkecambah minimal 80\% (Direktorat Perbenihan, 2009), sedangkan dayaberkecambah 
benih padi varietas Ciherang yang sudah melewati masa kadaluarsa maupun belum melewati masa kadaluarsa pada uji vigor tidak memenuhi standarisasi yang ditetapkan, karena benih yang diberi $\mathrm{GA}_{3}$ maupun yang hanya diberi perendamansaja mempunyai hasil yang sangat rendah yaitu 39-67\%. Ketentuan yang ditetapkan bahwa standarisasi untuk daya berkecambah yaitu minimal $80 \%$.

Tabel 5. Daya Berkecambah Uji Viabilitas dan Uji Vigor (\%)

\begin{tabular}{|c|c|c|c|}
\hline \multicolumn{2}{|c|}{ Perlakuan } & Uji Viabilitas & Uji Vigor \\
\hline & & DB (\%) & DB $(\%)$ \\
\hline \multirow{5}{*}{ Konsentrasi GA 3} & Kontrol positif $\left(\mathrm{g}_{0}\right)$ & $93.33 c$ & $67.66 b$ \\
\hline & Kontrol negatif $\left(\mathrm{g}_{1}\right)$ & $70.72 \mathrm{a}$ & $39.72 \mathrm{a}$ \\
\hline & $\mathrm{GA}_{3} 8 \mathrm{ppm}\left(\mathrm{g}_{2}\right)$ & $80.05 b$ & $53.27 \mathrm{ab}$ \\
\hline & $\mathrm{GA}_{3} 16 \mathrm{ppm}\left(\mathrm{g}_{3}\right)$ & $78.66 \mathrm{~b}$ & $56.83 b$ \\
\hline & $\mathrm{GA}_{3} 24 \mathrm{ppm}\left(\mathrm{g}_{4}\right)$ & $78.27 \mathrm{~b}$ & $58.05 \mathrm{~b}$ \\
\hline \multirow[t]{3}{*}{ Lama Perendaman } & 12 jam $\left(\mathrm{p}_{1}\right)$ & $76.65 a$ & $47 \mathrm{a}$ \\
\hline & $24 \operatorname{jam}\left(\mathrm{p}_{2}\right)$ & $80.25 b$ & $55.6 \mathrm{ab}$ \\
\hline & $36 \mathrm{jam}\left(\mathrm{p}_{3}\right)$ & $83.72 \mathrm{c}$ & $62.73 b$ \\
\hline
\end{tabular}

Keterangan: Angka rata-rata yang diikuti huruf yang sama pada arah vertikal, tidak berbeda nyata berdasarkan Uji Jarak berganda Duncan pada taraf nyata 5\%. kontrol positif $\left(\mathrm{g}_{0}\right)=$ Benih padi Ciherang belum melewati masa kadaluarsa dan kontrol negatif $\left(\mathrm{g}_{1}\right)=$ Benih padi Ciherang kadaluarsa.

Hendarto (2005) menyatakan bahwa penyimpanan yang kurang tepat akan menyebabkan kualitas benih dapat menurun secara drastis selama penyimpanan dan mengakibatkan meningkatnya laju deteriorasi yang tinggi sehingga viabilitas dan vigorbenih cepat menurun.

\section{Potensi Tumbuh Maksimum Uji Vibilitas dan Uji Vigor}

Hasil analisis menunjukkan tidak terjadi interaksi antara konsentrasi $\mathrm{GA}_{3}$ dan lama perendaman namun terjadi pengaruh secara mandiri konsentrasi $\mathrm{GA}_{3}$ terhadap potensi tumbuh maksimum (PTM) benih padi varietas Ciherang kadaluarsa pada Uji Viabilitas dan Vigor seperti yang ditunjukkan Tabel 6.

Tabel 6. PTM Uji Viabilitas dan Uji Vigor (\%)

\begin{tabular}{|c|c|c|c|}
\hline \multicolumn{2}{|c|}{ Perlakuan } & Uji Viabilitas & Uji Vigor \\
\hline & & PTM $(\%)$ & PTM (\%) \\
\hline \multirow{5}{*}{ Konsentrasi $\mathrm{GA}_{3}$} & Kontrol positif $\left(\mathrm{g}_{0}\right)$ & $96.78 \mathrm{c}$ & $91.77 \mathrm{c}$ \\
\hline & Kontrol negatif $\left(\mathrm{g}_{1}\right)$ & $83.44 \mathrm{a}$ & $80.11 \mathrm{a}$ \\
\hline & $\mathrm{GA}_{3} 8 \mathrm{ppm}\left(\mathrm{g}_{2}\right)$ & $87.11 \mathrm{ab}$ & $87.44 \mathrm{bc}$ \\
\hline & $\mathrm{GA}_{3} 16 \mathrm{ppm}\left(\mathrm{g}_{3}\right)$ & $89.11 b$ & $86.33 b$ \\
\hline & $\mathrm{GA}_{3} 24 \mathrm{ppm}\left(\mathrm{g}_{4}\right)$ & $87.44 \mathrm{ab}$ & $85.44 \mathrm{ab}$ \\
\hline \multirow[t]{3}{*}{ Lama Perendaman } & 12 jam $\left(\mathrm{p}_{1}\right)$ & $88.13 a$ & $85.40 \mathrm{a}$ \\
\hline & $24 \mathrm{jam}\left(\mathrm{p}_{2}\right)$ & $88.53 \mathrm{a}$ & $86.46 \mathrm{a}$ \\
\hline & 36 jam $\left(\mathrm{p}_{3}\right)$ & $89.66 \mathrm{a}$ & $86.80 \mathrm{a}$ \\
\hline
\end{tabular}


Keterangan: Angka rata-rata yang diikuti huruf yang sama pada arah vertikal, tidak berbeda nyata berdasarkan Uji Jarak berganda Duncan pada taraf nyata 5\%. kontrol positif $\left(\mathrm{g}_{0}\right)=$ Benih padi Ciherang belum melewati masa kadaluarsa dan kontrol negatif $\left(\mathrm{g}_{1}\right)=$ Benih padi Ciherang kadaluarsa.

Tabel 7 menunjukkan bahwa pengaruh mandiri pemberian konsentrasi GA 3 terhadap potensi tumbuh maksimum benih varietas Ciherang bahwa pemberian konsentrasi $\mathrm{GA}_{3} 16$ ppm mampu meningkatkan potensi tumbuh maksimum benih padi varietas Ciherang kadaluarsa hingga $89.11 \%$, dibandingkan dengan benih tanpa perlakuan pemberian $\mathrm{GA}_{3}\left(\mathrm{~g}_{1}\right)$ pada uji viabilitas yang hanya bisa mencapai $83.44 \%$ pada uji viabilitas.

Pemberian $\mathrm{GA}_{3}$ hampir mengimbangi potensi tumbuh maksimum benih padi varietas Ciherang belum melewati masa kadaluarsa $\left(\mathrm{g}_{0}\right)$ pada uji vigor namun pada ujiviabilitas pengaruh mandiri $\mathrm{GA}_{3}$ tidak mampu mengimbangi potensi tumbuh maksimum benih padi varietas Ciherang belum melewati masa kadaluarsa $\left(\mathrm{g}_{0}\right)$. Hal tersebut diduga karena kemampuan benih yang menurun pada saat penyimpanan dan pada proses uji coba pada kondisi optimum benih terserang patogen, mengakibatkan benih untuk tumbuh terhambat karena adanya patogen yang menyerang pada proses perkecambahan saat uji viabilitas. Penurunan viabilitas dikarenakan tingkat kematian benih dan meningkatnya perkembangan penyakit sehingga benih untuk tumbuh terhambat (Harahap dkk., 2015).

\section{Panjang Kecambah Uji Viabilitas dan Uji Vigor}

Hasil analisis menunjukkan tidak terjadi interaksi antara konsentrasi $\mathrm{GA}_{3}$ dan lama perendaman namun terjadi pengaruh secara mandiri konsentrasi $\mathrm{GA}_{3}$ terhadap panjang kecambah benih ciherang kadaluarsa pada Uji Viabilitas dan Vigor seperti yang ditunjukkan Tabel 8.

Tabel 8 menunjukkan bahwa pengaruh mandiri perlakuan pemberian konsentrasiGA $\mathrm{G}_{3}$ terhadap panjang kecambah benih padi varietas Ciherang kadaluarsa pada uji viabilitas terdapat perlakuan tertinggi, yaitu pemberian konsentrasi $\mathrm{GA}_{3} 24$ ppm dengan panjang kecambah $14.02 \mathrm{~cm}$ dibandingkan dengan panjang kecambah benih padi varietas Ciherang kadaluarsa tanpa diberi perlakuan $\mathrm{GA}_{3}\left(\mathrm{~g}_{1}\right)$ hanya dapat menghasilkan panjang kecambah $11.17 \mathrm{~cm}$. Perlakuan pemberian konsentrasi $\mathrm{GA}_{3} 24 \mathrm{ppm}$ mampu mengimbangi panjang kecambah benih padi varietas Ciherang belum melewati masa kadaluarsa $\left(\mathrm{g}_{0}\right)$ dengan hasil $14.19 \mathrm{~cm}$. Sedangkan pada uji vigor perlakuan pemberian konsentrasi GA 316 ppm merupakan perlakuan tertinggi dalam meningkatkan panjang kecambah benih padi varietas Ciherang kadaluarsa dengan hasil $15.6 \mathrm{~cm}$ dan mampu melebihi panjang kecambah benih padi Ciherang yang belum melewati masa kadaluarsa $\left(g_{0}\right)$ dengan hasil $14.72 \mathrm{~cm}$.

Pengaruh lamanya perendaman tidak menunjukkan pengaruh mandiri pada uji viabilitas dan uji vigor terhadap panjang kecambah benih padi varietas Ciherang didugakuat dikarenakan pengaruh lamanya perendaman tidak mampu mengimbangi panjangkecambah benih padi varietas Ciherang yang diberi konsentrasi $\mathrm{GA}_{3}$, diduga lamanya perendaman tidak bisa merangsang benih untuk tumbuh secara cepat dan optimal dikarenakan kualitas benih yang 
menurun dikarenakan faktor suhu dan kelembaban pada saat penyimpanan yang mengakibatkan benih tidak dapat tumbuh secara optimalpada proses perkecambahan.

Tabel 8. Panjang Kecambah Uji Viabilitas dan Uji Vigor (cm)

\begin{tabular}{llll}
\hline & Perlakuan & Uji Viabilitas & Uji Vigor \\
\hline & & PK $(\%)$ & PK $(\%)$ \\
\hline \multirow{4}{*}{ Konsentrasi GA $\mathrm{GA}_{3}$} & Kontrol positif $\left(\mathrm{g}_{0}\right)$ & $14.19 \mathrm{~b}$ & $14.72 \mathrm{~b}$ \\
& $\mathrm{GA}_{3} 8 \mathrm{ppm}\left(\mathrm{g}_{2}\right)$ & $11.17 \mathrm{a}$ & $10.78 \mathrm{a}$ \\
& $\mathrm{GA}_{3} 16 \mathrm{ppm}\left(\mathrm{g}_{3}\right)$ & $13.41 \mathrm{~b}$ & $13.65 \mathrm{ab}$ \\
& $\mathrm{GA}_{3} 24 \mathrm{ppm}\left(\mathrm{g}_{4}\right)$ & $14.03 \mathrm{~b}$ & $15.60 \mathrm{~b}$ \\
\hline Lama Perendaman & 12 jam $\left(\mathrm{p}_{1}\right)$ & $13.40 \mathrm{a}$ & $13.17 \mathrm{ab}$ \\
& 24 jam $\left(\mathrm{p}_{2}\right)$ & $12.90 \mathrm{a}$ & $13.53 \mathrm{a}$ \\
& 36 jam $\left(\mathrm{p}_{3}\right)$ & $13.73 \mathrm{a}$ & $13.36 \mathrm{a}$ \\
& & & $13.87 \mathrm{a}$ \\
\hline
\end{tabular}

Keterangan: Angka rata-rata yang diikuti huruf yang sama pada arah vertikal, tidak berbeda nyata berdasarkan Uji Jarak berganda Duncan pada taraf nyata $5 \%$. kontrol positif $\left(\mathrm{g}_{0}\right)=$ Benih padi Ciherang belum melewati masa kadaluarsa dan kontrol negatif $\left(\mathrm{g}_{1}\right)=$ Benih padi Ciherang kadaluarsa.

Giberelin memacu sintesa enzim proteolitik yang mampu melunakan dinding sel, sehingga akan melepaskan amino triptofan sehingga meningkatkan kadar auksin yang berperan dalam pembelahan sel. Giberelin juga berperan dalam memicu terbentuknya enzim amilase yang akan memecah amilumsehingga kadar gula di dalam sel akan naik menyebabkan air dapat masuk lebih banyaksehingga sel dapat memanjang (Salisbury dkk., 1995)

\section{. Rata-rata Berat kering Kecambah}

Hasil analisis menunjukkan terjadi pengaruh mandiri konsentrasi $\mathrm{GA}_{3}$ terhadap rata-rata berat kering kecambah normal $(\mathrm{BKKN})$ benih padi varietas ciherang kadaluarsa pada Uji Viabilitas dan Vigor seperti yang ditunjukkan Tabel 9.

Tabel 9. Rata-rata BKKN Uji Viabilitas dan Uji Vigor (mg)

\begin{tabular}{llcc}
\hline & Perlakuan & Uji Viabilitas & Uji Vigor \\
\hline & & BKKN $(\%)$ & BKKN $(\%)$ \\
\hline \multirow{4}{*}{ Konsentrol positif $\left(\mathrm{g}_{0}\right)$} & $20.00 \mathrm{~b}$ & $22.85 \mathrm{c}$ \\
& Kontrol negatif $\left(\mathrm{g}_{1}\right)$ & $17.55 \mathrm{a}$ & $18.61 \mathrm{a}$ \\
& $\mathrm{GA}_{3} 8 \mathrm{ppm}\left(\mathrm{g}_{2}\right)$ & $19.52 \mathrm{~b}$ & $20.99 \mathrm{abc}$ \\
& $\mathrm{GA}_{3} 16 \mathrm{ppm}\left(\mathrm{g}_{3}\right)$ & $18.78 \mathrm{~b}$ & $21.87 \mathrm{bc}$ \\
& $\mathrm{GA}_{3} 24 \mathrm{ppm}\left(\mathrm{g}_{4}\right)$ & $19.41 \mathrm{~b}$ & $19.13 \mathrm{ab}$ \\
\hline Lama Perendaman & 12 jam $\left(\mathrm{p}_{1}\right)$ & $19.23 \mathrm{a}$ & $21.37 \mathrm{a}$ \\
& 24 jam $\left(\mathrm{p}_{2}\right)$ & $18.82 \mathrm{a}$ & $19.80 \mathrm{a}$ \\
& 36 jam $\left(\mathrm{p}_{3}\right)$ & $19.10 \mathrm{a}$ & 20.90 \\
\hline
\end{tabular}

Keterangan: Angka rata-rata yang diikuti huruf yang sama pada arah vertikal, tidak berbeda nyata berdasarkan Uji Jarak berganda Duncan pada taraf nyata 5\%. kontrol positif $\left(\mathrm{g}_{0}\right)=$ Benih padi Ciherang belum melewati masa kadaluarsa dan kontrol 


$$
\text { negatif }\left(\mathrm{g}_{1}\right)=\text { Benih padi Ciherang kadaluarsa. }
$$

Tabel 9 menunjukka bahwa Pemberian konsentrasi $\mathrm{GA}_{3} 8$ ppm pada benih padi varietas Ciherang kadaluarsa mampu memberikan hasil tertinggi $19.52 \mathrm{mg}$, dibandingkan dengan hasil benih padi varietas Ciherang kadaluarsa tanpa diberi perlakuan $\mathrm{GA}_{3}\left(\mathrm{~g}_{1}\right)$. Sedangkan pada uji vigor perlakuan permberian $\mathrm{GA}_{3} 16$ ppm terhadap benih padi varietas Ciherang kadaluarsa memberikan hasil tertinggi dengan rata-rata berat kering mencapai $21.87 \mathrm{mg}$, dibandingkan dengan benih padi varietas Ciherang kadaluarsa tanpa diberi $\left(\mathrm{g}_{1}\right)$

Pengaruh pemberian konsentrasi $\mathrm{GA}_{3}$ dalam meningkatkan rata-rata berat kering kecambah normal berbeda nyata terhadap benih padi varietas Ciherang kadaluarsa $\left(\mathrm{g}_{1}\right)$,hal ini sesuai dengan hasil penelitian Wahyuni (2011) bahwa pemberian $\mathrm{GA}_{3}$ dengan konsentrasi 10 ppm mampu memberikan hasil tertinggi dalam meningkatkan berat kering batang kecambah pada benih padi hibrida mutu awal sedang. Prawiranata dkk (1992) menyatakan bahwa benih yang memiliki vigor yang tinggimampu menghasilkan berat kering kecambah normal yang tinggi baik pada kondisi optimum maupun suboptimum.

\section{Kesimpulan}

1. Pemberian kombinasi $\mathrm{GA}_{3} 24 \mathrm{ppm}$ dan lama perendaman 36 jam mampu meningkatkan kecepatan tumbuh $3.3 \%$ benih padi varietas Ciherang kadaluarsa pada kondisi optimum.

2. Pengaruh mandiri konsentrasi $\mathrm{GA}_{3} 8 \mathrm{ppm}$ meningkatkan daya berkecambah benih padi varietas Ciherang kadaluarsa pada kondisi optimum, pengaruh mandiri lama perendaman 36 jam dapat meningkatkan daya berkecambah benih padi varietas Ciherang pada kondisi optimum, pengaruh mandiri konsentrasi $\mathrm{GA}_{3} 16$ ppm mampu meningkatkan panjang kecambah dan berat kering kecambah normal benih padi varietas Ciherang kadaluarsa pada kondisi sub optimum.

\section{Daftar Pustaka}

Ance, G. dan Kartasapoetra. 1992. Teknologi Benih. Rineka Cipta, Jakarta.

Asra, R. dan Ubaidillah. 2012. Pengaruh Konsentrasi Giberelin $\left(\mathrm{GA}_{3}\right)$ Terhadap NilaiNutrisi (Callopogonium caeruleum). Jurnal-jurnal Ilmu Perternakan. Vol .15 (2).81- 82.

Balai Besar Penelitian Tanaman Padi Badan Penelitian dan Pengembangan Pertanian Dapartemen Pertanian. 2009. Deskripsi Padi. Balai Besar Penelitian Tanaman Padi. Subang.105 hal. bbpadi.litbang.pertanian.go.id. Diakses pada tanggal 20 Mei 2019.

Dapartemen Kesehatan RI. 1995. Daftar Komposisi Zat Gizi Pangan Indonesia.Direktorat Jendral pembinaan Kesehatan Masyarakat, Direktorat Bina Gizi Masyarakat, Pusat Penelitian dan Pengembangan Gizi. Jakarta. https://www.academia.edu/35116549/Daftar_Komposisi_Zat_Gizi_Pangan_Indo nesia_1995_DKBM_pdf. Diakses pada tanggal 20 Mei 2019. 
Direktorat Perbenihan. 2009. Persyaratan dan Tata Cara Sertifikasi Benih Bina Tanaman Pangan. Direktorat Jendral Tanaman Pangan, 173 hal.

Gomez, K. A., and A. A. Gomez. 2010. Prosedur Statistik untuk Penelitian Pertanian. UI. Press, Jakarta.

Harahap, A. A., Haryati., dan L. A. M. Siregar. 2015. Pengaruh Jenis dan Lama Perendaman Krioprotektan Terhadap Viabilitas Benih Rosella (Hibiscus sabdariffa L.) Secara Kriopeservasi. J. Online Agroteknologi. Vol. 3 (3) : 1140- 1146.

Hendarto, K. 2005. Dasar dasar Teknologi dan Sertifikasi Benih. Andi Offset. Yogyakarta.

Hopkin, W. G. 1995. Introduction to Plant Physiologi. Jhon Wiley \& Sons Inc. Singapore. 480 hal.

International Seed Testing Association (ISTA). 2010. Seed Science and Technology. International rules for seed testing. International Seed Testing Association. Zurich. $43 \mathrm{p}$.

Nurshanti, D. F. 2013. Tanggap Perkecambahan Benih Palem Ekor Tupai (Wodyetia bifurcate) terhadap ama Perendaman dalam Air. Jurnal Ilmiah AGRIBA. Vol. 2(9):216224.

Nugrohotomo, P. Y. dan A. Syukur. 2009. Upaya Peningkatan Hasil Benih Padi (Oryzasativa L.) Pada Berbagai Taraf Genangan Air dan Takaran Vermikompos di LahanSawah Irigasi Entisol. Jurnal ilmu-ilmu Pertanian Vol. 5(2). Jogjakarta.

Prawiranata, W., S. Harran., dan P. Tjndronegoro. 1992. Dasar-dasar Fisiologi Tumbuhan Jilid I. Dapartemen Botani. Fakultas Pertanian IPB, Bogor. 339 hal.

Pusat Data dan Sistem Informasi pertanin. 2018. Statistik Pertanian Tahun 2018. PusatData dan Sistem Informasi Pertanian Kementrian Pertanian Republik Indonesia, Jakarta. http://epublikasi.setjen.pertanian.go.id/download/file/438-statistik-pertanian- 2018. Diakses pada tanggal 20 Mei 2019.

Salisbury, B. Frank., dan C. W. Ross. 1995. Fisiologi Tumbuhan Jiid 1. Penerbit ITB, Bandung. 241 hal.

Supardy, E. Adelina, dan U. Made. 2016. Pengaruh Lama Perendaman dan Konsentrasi Giberelin $\left(\mathrm{GA}_{3}\right)$ Terhadap Viabilitas Benih Kakao (Theobroma cacao L.).e-j. Agrotekbis. Vol. 2(3) : 425-431. 
Sutopo, L. 2002. Teknologi Benih. Rajawali Press, Jakarta. 245 hal.

Vici, K. A., M. Tohir, dan M. Same. 2017. Pengaruh Waktu Perendaman dan Konsentrasi Giberelin $\left(\mathrm{GA}_{3}\right)$ pada Pertumbuhan Benih Cemara Laut (Casuarina equisetifolia L.). Jurnal AIP. Vol 5 (1) 29-38.

Wahyuni, S. 2011. Peningkatan Daya Kecambah dan Vigor Benih padi Hibrida Melalui Invigorasi. Penelitian Tanaman Pangan. Vol 30 (2) : 84-87.

Wattimena, G. A. 1998. Zat Pengatur Tumbuh Tanaman. PAU IPB, Bogor. 